\title{
Experiences of External Interference Among Finnish Journalists
}

\author{
Prevalence, methods and implications
}

\author{
Ilmari Hiltunen \\ COMET - Tampere Research Centre for Journalism, Media and Communication, \\ University of Tampere, Tampere, Finland.
}

\begin{abstract}
This study examines the prevalence, methods and implications of external interference among Finnish journalists based on survey responses from 875 working journalists. The definition of external interference used in the study encompasses all active and invasive methods external actors use to interfere in the journalistic process with the objective to influence editorial content. The findings indicate that low-level interference in everyday journalistic practices and mediated verbal abuse are the most frequent types of external interference. While severe interference is rare, results show that the perceived risk of interference causes concern and self-censorship among the respondents. The results are in line with previous Nordic and European studies, and underline how external interference may have detrimental effects on journalistic autonomy also in countries with strong legal, institutional and cultural safeguards of press freedom.
\end{abstract}

Keywords: journalism, autonomy, external interference, harassment, intimidation

\section{Introduction}

The democratic principles upholding the freedom of the press are being eroded in several European countries (Reporters Without Borders [RSF], 2017), and an increasingly hostile public discourse towards journalists and the media is spreading in the United States (Freedom House, 2017). These developments have raised concerns about the future of press freedom in Western countries and spurred growing research interest in emerging threats and challenges to journalism in democratic societies. Despite scholars' cautions about the deterioration of journalistic autonomy due to, for instance, increasing concentration of corporate control, commercialisation of news and competition among news organisations, Western democracies have tended to take it for granted (Reich \& Hanitzsch, 2013). Previous scholarly attention to the harassment and intimidation of journalists has largely focused on authoritarian or semi-democratic states with weak safeguards for media freedom and press autonomy (see Löfgren Nilsson \& Örnebring, 
2016), and the literature has generally reflected the absence of anti-press violence in Western nations (Waisbord, 2002).

The contemporary hybrid media ${ }^{1}$ environment has radically transformed the media landscape and the societal environment in which journalism operates by restructuring the authority, position and power of traditional media actors. In the online environment especially, journalists are more visible and accessible than ever and find their choices, credibility and integrity more often publicly contested (Löfgren Nilsson \& Örnebring, 2016). This exposes journalists to new detrimental phenomena like online harassment, cyberstalking and state-sponsored trolling campaigns (e.g. Luque Martinez, 2015). The techniques of external interference that journalists face are constantly shifting, and new methods are frequently introduced (Luostarinen, 1994).

Empirical research systematically assessing new threats and challenges to journalistic autonomy is therefore needed to identify these shifts and to develop effective responses. Nordic countries generally rank high in measures of media freedom and Finland topped the Press Freedom Index for seven consecutive times, from 2009 to 2016 (RSF, 2016a). Nonetheless, public concerns have arisen in Finland due to reports of rising online harassment and intimidation of journalists, and a media scandal over the prime minister's behind-the-scenes communication with public broadcaster Yleisradio Oy (YLE) regarding reporting of a potential conflict-of-interest case (see Finnish Newspapers Association, 2016; Haapalainen, 2016; Koivunen, 2017; RSF, 2016b).

The survey presented in this article represents a first attempt to provide a comprehensive empirical overview of external interference as experienced by Finnish journalists. The objective of the study is to explore the prevalence, methods and implications of external interference by measuring self-reported incidents of interference and the journalists' views of the effects of interference on their work. This type of overview is critically needed because previous research focusing on interference in the context of Finnish journalism is very scarce and limited both in scope and scale. This study also illustrates how external interference manifests itself in the context of a democratic Nordic country with strong legal, cultural and institutional safeguards for press autonomy. Since the 1960s, Finnish journalism has gradually sought to distance itself from political parties and newspapers have steadily rejected political party affiliations in favour of larger general audiences, proclaiming themselves independent (Nord, 2008). Moreover, the journalistic ideal in Finland strongly favours impartiality and objectivity. This is evident in the Worlds of Journalism Study (WJS) ${ }^{2}$ investigation of Finnish journalistic culture. Asked about perceived influences on journalistic work in Finland, journalists reported that censorship had the least effect on their work ( $73 \%$ stated it had no effect), followed closely by various external actors, such as the military and police, advertisers and advertising considerations, advocacy groups, media outlet owners, businesspersons and politicians. The results show a strong consensus among Finnish journalists on the autonomy of the profession and that they perceive themselves as distanced from direct political, government and business influences (Pöyhtäri et al., 2014: 12, 24-28).

\section{Theoretical framework and previous research}

Journalistic autonomy refers to journalists' ability to operate freely and independently and protect their work from all external influence (Deuze, 2005). Autonomy has tradi- 
tionally been viewed as a cornerstone of modern journalism in Western nations (Hanitzsch, 2011), distinguishing journalism from other forms of communication (Kunelius, 2003). Deuze (2005: 446) states that:

There seems to be a consensus among scholars in the field of journalism studies that what typifies more or less universal similarities in journalism can be defined as a shared occupational ideology among news workers which functions to selflegitimise their position in society.

Other elements of this shared occupational ideology include ideals of public service, objectivity, immediacy and ethics. However, journalistic autonomy functions as a prerequisite for the other elements. To be able to act as public watchdogs, report truthfully and consider ethical issues independently, journalists must enjoy editorial autonomy and freedom (Deuze, 2005; Kunelius, 2003).

Various external sources, operating on multiple levels, may impose limits on journalists' professional autonomy (Reich \& Hanitzsch, 2013). For the purposes of this study, external interference is defined as all active and invasive methods external actors use to interfere in the journalistic process and influence journalists with the objective of shaping editorial content (see also Luostarinen, 1994; Shoemaker \& Reese, 1996). Incidents of mixed interference are also included, defined as external interference intertwined with internal interference from within the media outlet, for example through editorial censorship (Hemánus, 1983). The definition of external interference used in this study, however, excludes standard public relations (PR) activities, such as press releases and conferences, information subsidies and other similar agenda-building efforts (Weaver \& Elliott, 1985).

Luostarinen (1994: 73-88) categorises three types of interference: repressive, restrictive and persuasive. Repressive methods include measures of physical, economic, political and occupational pressure. Occupational pressure refers to measures intended to publicly discredit journalists or media outlets. In addition, judicial and psychological pressure can also be categorised as repressive methods. Judicial pressure refers to using legal measures as pressure tactics, while psychological pressure can result from any of these methods but is most often associated with harassment and intimidation explicitly used to provoke negative psychological reactions (Clark \& Grech, 2017). Restrictive methods include ways to hinder journalistic work such as blocking access to and withholding information. Thirdly, persuasive methods include bribery and corruption but also measures such as providing privileged access in exchange for influence over journalistic content (Luostarinen, 1994).

Studies and surveys in Nordic and European countries (Clark \& Grech, 2017; Landsverk-Hagen, 2015; Löfgren Nilsson, 2016; Löfgren Nilsson \& Örnebring, 2016; Marttinen, 2016) indicate that verbal abuse, harassment and intimidation have the potential to cause fear, self-censorship and a chilling effect among journalists. In a 2016 survey (Marttinen, 2016) in Finland, 16 per cent of working members of the Union of Journalists reported having received threatening messages in recent years. In the Swedish Journalist Panel Survey (Löfgren Nilsson, 2016), approximately 30 per cent of Swedish journalists reported having received threats, and two out of three had been subjected to verbal abuse during the past 12 months. In a study from 2013, 26 per cent of Swedish journalists who had received threats reported that they at least occasionally avoided covering specific issues and 30 per cent avoided covering specific persons and groups 
(Löfgren Nilsson \& Örnebring, 2016). The number was slightly lower (17\%) among those who had received abusive comments. The researchers concluded that verbal abuse, intimidation and harassment somewhat effectively silence journalists and influence the journalistic public sphere even in stable, democratic societies such as Sweden (Löfgren Nilsson \& Örnebring, 2016: 888-890). Studying Norway, Landsverk-Hagen (2015) found that close to half ( $43 \%$ of men and $44 \%$ of women) of the journalists reported having experienced online harassment, defamation or verbal abuse and a quarter $(27 \%$ of men and $23 \%$ of women) had received threats during the past five years. Furthermore, 21 per cent thought that harassment and threats might affect their future reporting. The number was somewhat higher (24\%) among the respondents who had experienced harassment or threats. In a European study exploring experiences of unwarranted interference among 940 journalists in Council of Europe member states and Belarus, the respondents reported high rates of self-censorship and other direct effects as a result of external interference (Clark \& Grech, 2017). In the same study, 37 per cent reported that unwarranted interference had affected how they performed their work (Clark \& Grech, 2017: 43-44).

This survey extends the scope of previous studies by examining a wider variety of external interference used to undermine or violate journalistic autonomy. In that way, incidents of low-intensity interference, closely related to journalistic practices, can be observed alongside more aggressive methods. Therefore, the study provides a nuanced picture of the contemporary journalistic environment in which Finnish journalists conduct their work. The research questions are:

1. What kinds of external interference methods have Finnish journalists encountered?

2. How frequently do Finnish journalists encounter different methods of external interference?

3. How does external interference affect the work of Finnish journalists?

\section{Methodology}

This study has an exploratory character and aims to document characteristics of a social phenomenon of which very little previous empirical research exists (Jann \& Hinz, 2016). An anonymous, self-report online questionnaire was used to explore the methods, frequency and implications of external interference experienced by Finnish journalists. ${ }^{3}$ Survey methodology was chosen because incidents of low-intensity interference and harassment, in particular, often go unreported and unrecorded. Self-report surveys are useful tools to uncover previously undocumented personal experiences and perceptions (Clark \& Grech, 2017). The questionnaire consisted of seven background questions, 41 closed multiple-choice questions, 15 Likert scale questions and four optional fields for open-ended text comments. The reference period in the questionnaire was the past three years (2014-2017), which was considered to be sufficiently long to provide a consistent overview while mitigating possible reliability issues.

When studying special populations like employees in specific occupations, it is appropriate to utilise readily available lists of group members (Sudman \& Kalton, 1986). Due to the very high organisation rate of journalists in Finland ${ }^{4}$, the exhaustive and upto-date nature of the national registry of the Union of Journalists in Finland, and the fact that the Union of Journalists and three Finnish editors' associations (whose membership 
include editors-in-chief, managing editors and other journalists who exercise significant power over terms of employment and whose main work responsibilities include overseeing the financial benefits of companies) assisted in administering the survey, it was possible to effectively reach almost the entire national population of working journalists. Pöyhtäri and colleagues (2014) estimate that working journalists in Finland number roughly 8,000 , indicating that the total of 8,275 survey recipients included close to the whole national population.

Over the two-week data collection period (13-26 March, 2017), the survey was distributed by e-mail to 7,944 working members of the Union of Journalists in Finland, 113 members of the Finnish Association of Editors, 120 members of the Finnish Association of Magazine Editors-in-Chief and 98 members of the Association for Local Paper Editorsin-Chief. The definition of journalist used in this study is consistent with the union or editors' association membership requirements. ${ }^{5}$ After two reminders, 875 responses in total were received, representing a participation rate of 10.6 per cent. ${ }^{6}$ The response rate was objectively low even for a web-based survey (cf. Cook et al., 2000), which should be kept in mind when examining the findings. However, Krosnick (1999) states that surveys with low response rates can yield useful data, highlighting the importance of sample composition. Moreover, 353 respondents (40\%) provided one or more text comments to supplement their responses.

To assess the survey sample, the representative sample constructed for the WJS study (Pöyhtäri et al., 2014) and the Union of Journalists in Finland membership statistics were used as reference points. This comparison indicated that the survey sample matched the proportions of the estimated target population reasonably well with regards to factors like gender, age, position, type of employment and employing media outlet. This is illustrated in Table 1 below.

Table 1. Survey sample in comparison (per cent)

\begin{tabular}{|c|c|c|c|}
\hline & Survey sample & $\begin{array}{l}\text { WJS sample } \\
\text { (Finland) }\end{array}$ & $\begin{array}{l}\text { Union of Journalists } \\
\text { in Finland members } \\
\end{array}$ \\
\hline Gender distribution (Female/Male) & $57 / 43$ & $55 / 45$ & $57 / 43$ \\
\hline Dominant age group & $36-55$ years $(54 \%)$ & $36-55$ years $(61 \%)$ & $36-55$ years $(55 \%)$ \\
\hline Salaried employees & 81 & 82 & 81 \\
\hline Freelancers or entrepreneurs & 15 & 17 & 18 \\
\hline Working for newspapers or magazines & 65 & 69 & 67 \\
\hline $\begin{array}{l}\text { Working for broadcasting (including } \\
\text { public broadcasting) }\end{array}$ & 23 & 23 & 32 \\
\hline $\begin{array}{l}\text { Position as reporter, special } \\
\text { reporter or visual journalist }\end{array}$ & 68 & 72 & 76 \\
\hline $\begin{array}{l}\text { Managerial position (Managing editor, } \\
\text { producer, editor-in-chief, etc.) }\end{array}$ & 28 & 24 & $15^{8}$ \\
\hline
\end{tabular}

The most noteworthy bias in the sample was the overrepresentation of managing editors and especially editors-in-chief (10\% editors-in-chief in the survey sample compared to $4 \%$ in the WJS sample), largely explained by the inclusion of three editors' associations in the survey. 
While the proportional similarities do not make the sample representative of the population of Finnish journalists, they increase confidence in that no one group dominated the sample or skewed the results significantly. Considering the high absolute number of respondents amounting to over one tenth of the estimated national journalist population, the sample contains substantial internal variety. This fulfils the research aim of capturing a large overview of external interference across the whole field of Finnish journalism. Nonetheless, the survey sample contains several limitations, namely due to the nonprobability, self-selection sampling method and the low overall response rate. First of all, surveys are prone to biases derived from issue salience (Cook et al., 2000) and nonresponse, which can lead to more input from respondents with a personal connection to, or extreme opinions on, the subject. To minimise such effects, the cover letter explicitly encouraged participation even if the recipient had no personal experience of any external interference. It is however still possible that the amount of external interference experienced by the journalists in the survey sample might be higher than in the whole population, reducing the ability to generalise from the sample to the whole population (Sivo et al., 2006). Additionally, it should be noted that the frequency of certain elements of journalistic work logically increases the likelihood of journalists encountering certain types of interference. To improve the internal validity of the survey, respondents were given the option to answer "Don't know/No opinion" when the question was not applicable or relevant to their work as a journalist. Still, for example, a journalist conducting interviews regularly is statistically more likely to experience interference in an interview setting than one that rarely conducts any. Because of these limitations and the lack of previous empirical research on the subject, the study results should be considered as indicative and illustrative rather than representative and definitive.

\section{Findings}

The results are presented in three sections: 1) frequency and methods of external interference; 2) reactions to external interference; and 3) perceived implications of external interference. In the first two sections, journalists were asked to estimate how often they have on average encountered described external interference during the last three years. Responses of "once every three months", "once every month" and "once a week or more frequently" were combined to form a merged category "regularly". Direct extracts from open survey comments are used to illustrate how journalists reflected on the different themes.

\section{Prevalence and methods of external interference}

This section addresses methods of low-intensity interference related to interviewing and access to sources and information (Table 2) and screening of journalistic content before publication (Table 3), ${ }^{9}$ which are closely connected to the power relations between journalists and their sources. The growing role of professional PR and its increasing efforts to control journalistic content has previously attracted attention among Finnish journalists (see Pietiläinen, 2007). In the WJS study, an interesting contradiction regarding this was observed: Finnish journalists reported that the overall influence of advertisers and PR-actors in journalism has increased while simultaneously stating that 
these actors had very little influence on their journalistic work (Pöyhtäri et al., 2014). Table 2 provides an overview of the frequency of various types of low-intensity external interference among the respondents.

Table 2. External interference with regards to interview situations and access to information (per cent)

\begin{tabular}{lccccc} 
& Regularly & $\begin{array}{c}\text { Once } \\
\text { every six } \\
\text { months }\end{array}$ & $\begin{array}{c}\text { Once a } \\
\text { year or } \\
\text { less }\end{array}$ & Never & $\begin{array}{c}\text { Don't } \\
\text { know/No } \\
\text { opinion }\end{array}$ \\
\hline $\begin{array}{l}\text { Demands to see the questions as a } \\
\text { prerequisite for interviews }\end{array}$ & 21 & 14 & 30 & 33 & 3 \\
$\begin{array}{l}\text { Unwarranted presence of PR } \\
\text { persons during interviews or phone } \\
\text { interviews }\end{array}$ & 10 & 13 & 34 & 41 & 2 \\
$\begin{array}{l}\text { Denial or obstruction of access to } \\
\text { public information }\end{array}$ & 10 & 11 & 27 & 46 & 5 \\
$\begin{array}{l}\text { Demands to exclude certain topics } \\
\text { or questions from interviews }\end{array}$ & 6 & 12 & 29 & 49 & 3 \\
$\begin{array}{l}\text { Withholding of cooperation with } \\
\text { certain journalists }\end{array}$ & 3 & 6 & 20 & 67 & 4 \\
\hline
\end{tabular}

Comment: $\mathrm{n}=875$. As percentages in the tables are rounded to the nearest whole per cent, the total may not always add up to 100 per cent.

The survey responses and text comments indicated that it was relatively common that interviewees required special conditions for participating in interviews. This supports previous notions of the proliferation of professional PR and strategic communications efforts in Finland (e.g. Kantola \& Lounasmeri, 2014; Pietiläinen, 2007). In addition to corporations, PR professionals are employed by politicians, government institutions and organisations and make their presence felt by monitoring and controlling interviews and restricting access to information and sources. The open answers extracted below illustrate this type of interference:

Inside the Police and the Defence Forces there are interviewees who decline to provide public documents, arrive to interviews with big PR-crowds and discredit factual journalism pieces by supplying false corrections after the publication. (translation by author)

When I have covered big corporations [...], their spokesperson or chief communications officer is always present for the whole interview. You cannot even get an interview without asking the communications department first. [...] Sometimes they have insisted that the journalism piece has to be sent to them before publication. (translation by author)

Almost one third (29\%) of the respondents reported having experienced explicit withholding of cooperation. This might indicate sources' efforts to pre-emptively cherry-pick journalists and provide access only to those providing positive coverage while ostracising those considered more critical.

Nearly half (48\%) of the respondents had experienced withholding or obstruction of access to public information. While the question was not restricted to public govern- 
mental information, it is worth pointing out that researchers (see Kuutti, 2011) having previously documented problems in government authorities' ability and willingness to provide public documents when requested, despite the Finnish Act on the Openness of Government Activities ensuring broad access to all material not specifically labelled restricted. This is noteworthy considering that in the WJS study, 40 per cent of Finnish journalists regarded access to official information as either "very" or "extremely" important to their work (Pöyhtäri et al., 2014: 27).

The next section goes on to discuss external interference in the shape of demands for pre-screening of content. The questions assessing such methods are summarised in Table 3.

Table 3. External interference with regards to pre-screening of journalistic content (per cent)

\begin{tabular}{lccccc} 
& Regularly & $\begin{array}{c}\text { Once } \\
\text { every six } \\
\text { months }\end{array}$ & $\begin{array}{c}\text { Once a } \\
\text { year or } \\
\text { less }\end{array}$ & Never & $\begin{array}{c}\text { Don't } \\
\text { know/No } \\
\text { opinion }\end{array}$ \\
\hline $\begin{array}{l}\text { Demands to inspect whole jour- } \\
\text { nalism pieces as prerequisites for } \\
\text { interviews }\end{array}$ & 22 & 13 & 24 & 39 & 2 \\
$\begin{array}{l}\text { Demands for journalistically unwar- } \\
\text { ranted alterations to (direct or }\end{array}$ & 20 & 17 & 29 & 31 & 2 \\
$\begin{array}{l}\text { indirect) quotations in the journal- } \\
\text { ism piece after interviews }\end{array}$ & & & & & \\
$\begin{array}{l}\text { Demands for journalistically unwar- } \\
\text { ranted alterations to other parts of } \\
\text { journalism pieces after interviews } \\
\text { (e.g. headline, lead paragraph, text, } \\
\text { images and other visual elements) }\end{array}$ & 13 & 16 & 33 & 36 & 2 \\
$\begin{array}{l}\text { Journalistically unwarranted } \\
\text { demands to not publish pieces and } \\
\text { interviews }\end{array}$ & 1 & 4 & 34 & 60 & 1 \\
\hline
\end{tabular}

Comment: $\mathrm{n}=875$. As percentages in the tables are rounded to the nearest whole per cent, the total may not always add up to 100 per cent.

Pre-screening content before publication provides an interesting example of the blurred lines between journalism practice, ethical considerations and external interference. A significant number of respondents reflected on the ethical and societal implications of pre-screening in their open answers. They also mentioned benefits: an opportunity to correct factual mistakes and misunderstandings before publication, especially in subject matter requiring a high level of expertise, and a means to build confidence between journalists and interviewees when covering sensitive topics:

It is common that the interviewee reads a long feature piece before publication.

That way one can weed out small mistakes, correcting of which afterwards would be arduous and awkward for everyone involved. (translation by author)

Based on the survey comments, respondents typically assessed demands to alter journalistic content in some way in two steps. First, respondents considered the status of the person making the request. Politicians, celebrities and other wielders of political and economic power were treated more strictly than ordinary citizens unaccustomed to dealing with journalists and the media. Second, the respondents considered the societal importance of the subject matter. They mentioned that removing and altering some trivial 
aspects, wordings and details that had little to no societal importance was regarded as standard procedure. If the merits of publishing outweighed the harm done, a story was published in the original form despite the desires of the interviewees or others involved. This evaluation process reflects the established tradition of Finnish journalism ethics setting out four levels of privacy protection based on the issue and individual status. The affairs of public figures enjoy the lowest level of protection, while private matters of private persons enjoy the highest (Mäntylä, 2008).

The next section goes on to discuss non-physical methods of external interference directed towards journalists and editors. Verbal pressure and other non-physical methods of interference often cause negative psychological effects (Clark \& Grech, 2017). Table 4 summarises the degree to which the respondents were exposed to various kinds of non-physical interference.

Table 4. Non-physical forms of external interference (per cent)

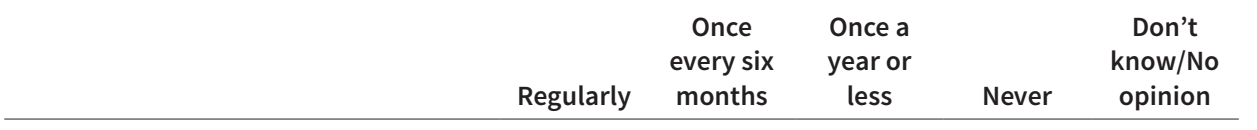

Mediated verbal abuse (e.g. insults, name-calling or other verbal expressions of hate through phone calls, letters, email, online comments, social media and websites)

15

Contacting and pressuring the editor, managing editor or owner of a media outlet

Systematic or unusually large volumes of feedback (e.g. organised feedback campaigns)

Face-to-face verbal abuse (e.g. insults, name-calling and other verbal expressions of hate)

Threats of negative occupational consequences (e.g. loss of work or journalistic credibility, hampering of future work)

Public defamation through spreading false claims, rumours or publishing sensitive private information (also online)

Threats of negative personal consequences (e.g. loss of reputation, harm to personal life)

Direct or implicit threats of violence

Threats to destroy personal or employer property

Direct or implicit threats of violence or other harmful consequences for your family, loved ones and friends

Hacking attempts and digital security breaches (e.g. breaking into email, personal files and social media profiles)

4

3

3

3

2

1

0

0

0
14

11

36

41

5

5

16

74

2

5

29

63

0

4

23

68

1

$\begin{array}{llll}2 & 12 & 79 & 4\end{array}$

Comment: $n=875$. As percentages in the tables are rounded to the nearest whole per cent, the total may not always add up to 100 per cent. 
Among the various types of non-physical interference, verbal abuse through different communication channels stood out as more frequent; 60 per cent of respondents had experienced it, and 15 per cent did so regularly. Based on similarly high numbers in Sweden, Löfgren Nilsson and Örnebring (2016) concluded that for many journalists, verbal abuse has become a common element of daily work, attributed to the increased online accessibility and visibility of the journalist profession. This interpretation is supported by numerous survey comments describing verbal abuse and harassment on social media and various online platforms:

I am being regularly verbally abused in online forums, Facebook groups and comment sections. The abuse targets my appearance, my supposed political commitments and often my gender. They have implied that I have sex with my superiors and interviewees, explicitly called me a whore and suggested that I will see the error of my ways when I get raped. (translation by author)

The mental strain of the work has increased exponentially over the last five years. Nowadays verbal abuse, ridicule and intimidation are weekly occurrences. Before they were rare. (translation by author)

In the comments, public defamation was often associated with the online environment. Aggressive counter-media websites and online discussion forums were typically mentioned as facilitators of crowdsourced harassment campaigns. With regards to the former, Noppari and Hiltunen (2018) describe online counter media as media websites that promote certain (often radical or fringe) political and ideological positions. These websites regularly publish commentary texts with the explicit objective of refuting and discrediting journalism pieces and journalists of "mainstream media". Occasionally, personal information, contact details or pictures of journalists are published alongside. As discussed in the quote below, defamatory and abusive content distributed online made individual journalists the targets of verbal abuse, harassment and threats by a large online audience.

There have been organised online hate campaigns against me with the explicit aim of getting me fired [...] For example, they have distributed the contact information of my superiors accompanied with bogus claims based on which I should lose my job. Some have actually contacted my media outlet based on these claims. (translation by author)

This follows the logic of weaponised online visibility (see Trottier, 2017) and highlights how participatory networked communication infrastructure can be utilised to organise systematic harassment (e.g. Luque Martinez, 2015).

When it comes to intimidation, a combined total of 18 per cent of respondents reported receiving direct or implicit threats of violence, threats to destroy property and/ or harm loved ones during the past three years.

Next, the article discusses the prevalence of different kinds of physical pressure, ranging from following journalists around while they are working to outright physical abuse.

As shown in Table 5, physical pressure against journalists may include violence, physically interfering with the performance of journalistic work and tampering with or destroying working equipment. 
Table 5. Physical forms of external interference (per cent)

\begin{tabular}{|c|c|c|c|c|c|}
\hline & Regularly & $\begin{array}{l}\text { Once } \\
\text { every six } \\
\text { months }\end{array}$ & $\begin{array}{l}\text { Once a } \\
\text { year or } \\
\text { less }\end{array}$ & Never & $\begin{array}{l}\text { Don't } \\
\text { know/No } \\
\text { opinion }\end{array}$ \\
\hline $\begin{array}{l}\text { Monitoring and following while con- } \\
\text { ducting journalistic work }\end{array}$ & 1 & 2 & 14 & 81 & 1 \\
\hline $\begin{array}{l}\text { Unwarranted denial of entry or } \\
\text { removal while conducting journalistic } \\
\text { work }\end{array}$ & 1 & 2 & 13 & 83 & 1 \\
\hline $\begin{array}{l}\text { Disruptions of work (e.g. heckling } \\
\text { and disrupting interviews and other } \\
\text { journalistic work) }\end{array}$ & 1 & 1 & 13 & 84 & 0 \\
\hline $\begin{array}{l}\text { Minor physical violence (e.g. push- } \\
\text { ing, shoving, hair pulling, grabbing or } \\
\text { spitting) }\end{array}$ & 0 & 0 & 4 & 96 & 0 \\
\hline $\begin{array}{l}\text { Tampering with or breaking working } \\
\text { equipment (e.g. cameras, recorders } \\
\text { and notebooks) }\end{array}$ & 0 & 0 & 3 & 96 & 0 \\
\hline $\begin{array}{l}\text { Serious physical violence (e.g. at- } \\
\text { tacking, hitting, kicking or throwing } \\
\text { objects) }\end{array}$ & 0 & 0 & 1 & 99 & 0 \\
\hline
\end{tabular}

Comment: $\mathrm{n}=875$. As percentages in the tables are rounded to the nearest whole percent, the total may not always add up to 100 percent

While explicit physical violence was rare, a few survey comments brought up that they experienced an increased threat when covering demonstrations. Based on these comments, hostile attitudes towards media and journalists had been manifested as pushing, shoving, tripping and verbal aggression during such protests.

Having discussed the occurrence of physical and non-physical methods of external interference, the following sections focus on institutional and economic pressure exercised against journalists. Institutional pressure refers to methods of interference operating through societal institutions, such as the legal system or media self-regulation. Table 6 summarises the survey results concerning this kind of interference.

Table 6. Institutional forms of external interference (per cent)

\begin{tabular}{|c|c|c|c|c|c|}
\hline & Regularly & $\begin{array}{c}\text { Once } \\
\text { every six } \\
\text { months }\end{array}$ & $\begin{array}{c}\text { Once a } \\
\text { year or } \\
\text { less }\end{array}$ & Never & $\begin{array}{c}\text { Don't } \\
\text { know/No } \\
\text { opinion }\end{array}$ \\
\hline $\begin{array}{l}\text { Threatening with or issuing a com- } \\
\text { plaint to the Finnish Council for }\end{array}$ & & & & & \\
\hline Mass Media with intent to pressure & 3 & 5 & 26 & 65 & 0 \\
\hline $\begin{array}{l}\text { Threatening with or commencing } \\
\text { legal action }\end{array}$ & 2 & 4 & 29 & 65 & 0 \\
\hline $\begin{array}{l}\text { Threatening with or suing for dam- } \\
\text { ages or compensation }\end{array}$ & 1 & 3 & 21 & 75 & 0 \\
\hline
\end{tabular}

Comment: $n=875$. As percentages in the tables are rounded to the nearest whole per cent, the total may not always add up to 100 per cent. 
Judicial pressure seems to be used occasionally, with 35 per cent of respondents having been threatened with court cases and 25 per cent with lawsuits for damages at least once during the reference period. The Finnish Council for Mass Media (2016) has acknowledged a rising trend in using their self-regulatory procedures to pressure and harass journalists. As a result, the Council has publicly declared that complaints made with these motives will be discarded outright.

The survey also asked respondents about experiences of different kinds of economic pressure. Table 7 shows the prevalence of economic pressure exercised towards journalists and editors, such as attempts to influence content by offering gifts or threatening to negatively affect sponsors to withdraw support for the media outlet in question.

Table 7. Economic forms of external interference (per cent)

\begin{tabular}{|c|c|c|c|c|c|}
\hline & Regularly & $\begin{array}{l}\text { Once } \\
\text { every six } \\
\text { months }\end{array}$ & $\begin{array}{l}\text { Once a } \\
\text { year or } \\
\text { less }\end{array}$ & Never & $\begin{array}{l}\text { Don't } \\
\text { know/No } \\
\text { opinion }\end{array}$ \\
\hline $\begin{array}{l}\text { Threats of loss of subscribers or } \\
\text { audiences for media outlets }\end{array}$ & 11 & 9 & 22 & 52 & 6 \\
\hline $\begin{array}{l}\text { Threats of loss of advertisements } \\
\text { and sponsors or other economic } \\
\text { sanctions for media outlets }\end{array}$ & 4 & 7 & 19 & 62 & 8 \\
\hline $\begin{array}{l}\text { Offers of economically valuable } \\
\text { benefits or gifts }\end{array}$ & 2 & 6 & 18 & 73 & 1 \\
\hline $\begin{array}{l}\text { Explicit offers of economic benefit } \\
\text { in exchange for influence over } \\
\text { journalistic content (bribery) }\end{array}$ & 0 & 0 & 5 & 94 & 0 \\
\hline
\end{tabular}

Comment: $n=875$. As percentages in the tables are rounded to the nearest whole per cent, the total may not always add up to 100 pe rcent.

Significant differences can be observed in the frequencies of explicit bribery attempts and gift-giving with implicit expectations of positive coverage. Luostarinen (1994) states that a considerable grey area exists between material corruption and normal journalistic practices involving free items, such as sample products and services and event and travel tickets. However, the comments indicated that the acceptance of even minor gifts prompted self-reflection on ethical considerations, highlighting the significance of professional ethics. In the WJS study, Finnish journalists identified taking money from a source as the most indefensible ethical violation, with 99 per cent of journalists condemning it under any circumstances (Pöyhtäri et al., 2014: 20).

Against the background of these findings on the occurrence of various types of external interference, the next section discusses respondents' strategies and routines to manage external attempts to interfere with journalistic work.

\section{Reactions to external interference}

This section discusses how the respondents manage external interference in their daily work. As shown in Table 8, such strategies may include reporting incidences of interference to colleagues or superiors, adjusting content or making the interference publicly known by reporting or writing about it. 
Table 8. Reactions to external interference (per cent)

\begin{tabular}{|c|c|c|c|c|c|}
\hline & Regularly & $\begin{array}{l}\text { Once } \\
\text { every six } \\
\text { months }\end{array}$ & $\begin{array}{l}\text { Once a } \\
\text { year or } \\
\text { less }\end{array}$ & Never & $\begin{array}{l}\text { Don't } \\
\text { know/No } \\
\text { opinion }\end{array}$ \\
\hline $\begin{array}{l}\text { How often have you told your } \\
\text { colleagues about incidents of } \\
\text { external interference? }\end{array}$ & 14 & 15 & 42 & 28 & 2 \\
\hline $\begin{array}{l}\text { How often have you let interview- } \\
\text { ees alter their citations without } \\
\text { journalistic grounds? }\end{array}$ & 11 & 12 & 27 & 47 & 3 \\
\hline $\begin{array}{l}\text { How often have you told your edi- } \\
\text { tor or employer about incidents of } \\
\text { external interference? }\end{array}$ & 10 & 12 & 44 & 32 & 3 \\
\hline $\begin{array}{l}\text { How often have you altered jour- } \\
\text { nalism pieces in some way due to } \\
\text { external interference? }\end{array}$ & 5 & 7 & 23 & 63 & 2 \\
\hline $\begin{array}{l}\text { How often has your editor or } \\
\text { employer altered your journalism } \\
\text { pieces against your will due to } \\
\text { external interference? }\end{array}$ & 2 & 3 & 17 & 75 & 4 \\
\hline $\begin{array}{l}\text { How often have you published } \\
\text { accounts of the interference you } \\
\text { have encountered (e.g. in journal- } \\
\text { ism pieces)? }\end{array}$ & 1 & 2 & 16 & 80 & 2 \\
\hline $\begin{array}{l}\text { How often has your editor or em- } \\
\text { ployer decided not to publish your } \\
\text { journalism pieces against your will } \\
\text { due to external interference? }\end{array}$ & 0 & 1 & 7 & 89 & 3 \\
\hline $\begin{array}{l}\text { How often have you decided to } \\
\text { not publish journalism pieces due } \\
\text { to external interference? }\end{array}$ & 0 & 0 & 11 & 88 & 1 \\
\hline
\end{tabular}

Comment: $n=875$. As percentages in the tables are rounded to the nearest whole per cent, the total may not always add up to 100 per cent.

Strategies of altering journalistic content before publication are closely related to demands to pre-screen content before publication. Based on the open answers, respondents often made concessions to alter trivial details or wordings. Perhaps more worrisome were incidents of pieces not being published at all, or when editors and owners interfered (i.e. causing mixed interference). The comments concerning this issue described incidents of superiors giving in to external interference, often due to the perceived economic and political incentives or leverage wielded by the perpetrators. The quote below is one example of such a situation:

Commercialism is a huge challenge to local radio stations that are dependent on ad revenue. All programmes and interviewees are planned on the basis of who advertises on the channel. We are not allowed to let anybody else on air. I feel that the editorial staff does not have any say when it comes to choosing interviewees [...]. (translation by author)

The respondents described these as demoralising experiences, breaching ethical obligations to the public and creating a source of mistrust towards editors and management. 
This indicated that even minor concessions to external actors were easily interpreted as questioning journalists' professionalism or as indicating lack of editorial or managerial support.

Some respondents stated that external actors strategically exploited the perceived weaknesses in the editorial chain of command. Instead of pressuring reporters, they directly approached editors and owners. In a study exploring the relationships and dynamics between the power elite and the media in Finland (Kunelius et al., 2010), elite interviewees described Finnish journalism as mostly autonomous but acknowledged that well-timed strategic contacts and behind-the-scenes communication with editors could be used to balance or subdue critical reporting. This was in line with the survey responses indicating that complete abandonment of stories was rare compared to making alterations, such as toning down critical stories, excluding some sensitive elements or facts and reporting in a less controversial manner.

\section{Perceived implications of external interference}

This section focuses on journalists' perceptions of how external interference may affect their work or the journalistic profession in general, measured using a standard Likert scale. Table 9 summarises the responses to questions concerning the perceived implications of external interference.

Over one sixth (17\%) of the respondents agreed that they felt uncomfortable when reporting on certain subjects and viewpoints, and 14 per cent reported performing self-censorship due to the risk of interference. More than two-thirds (69\%) expressed concerns about how external interference affects the credibility of Finnish journalism, several comments attributing this to increased commercial and PR influence and perceived audience hostility towards journalists.

When reflecting on whether the audience has the right to know about attempts of external interference, the respondents stressed careful consideration, ethical discretion and a sense of proportion. The survey comments often specified that matters should be made public only in cases where interference was exceptionally aggressive, or the perpetrator had a position with substantial societal power (see Mäntylä, 2008). Ill-considered or excessive focus on interference was often seen as diverting public attention from more important issues to journalism itself. Some noted that politicians, officials and corporations naturally try to influence their media portrayal, so the respondents dismissed interference as "part of the job" or "just business". A few respondents pointed out that Finnish journalistic culture might be experiencing a cultural shift regarding this matter (see also Koivunen, 2017):

Politicians have always made angry phone calls to editors/reporters. [...] according to my observations, younger journalists do not consider these as part of normal professional interaction anymore. I think this is a healthy development. Considering this cultural change, I think that the strong emotional reaction of [prime minister] Sipilä deserved a public treatment. (translation by author)

Survey respondents were generally confident in their ability and that of their media outlets to resist and ward off external interference. However, some statements revealed distinctly polarised trends among journalists on whether the external interference 
Experiences of External Interference Among Finnish Journalists

Table 9. Perceived implications of external interference (per cent)

\begin{tabular}{ccccc} 
Strongly & Neither & Don't \\
agree & Agree & $\begin{array}{c}\text { agreer } \\
\text { disagree }\end{array}$ Disagree & $\begin{array}{c}\text { Strongly } \\
\text { disagree }\end{array}$ opinion \\
\hline
\end{tabular}

I am confident that my editor or employer will support me from external interference.

46

My media outlet does not hand over control of journalistic decisions to external actors under any circumstances.

I am worried about the effects of external interference on the credibility of journalism in Finland.

External interference does not affect my journalistic work in any way.

The audience has a right to know about all incidents of external interference; therefore, they should always be made public.

External interference increases the mental strain of my work.

The credibility of my media outlet would decrease if all the concessions made due to external interference were made public.

15

18

16

21

16

15

I have consciously developed methods and strategies to ward off external interference.

10

34

21

12

14

9

Advertisers and sponsors are able to influence the journalism my media outlet produces.

9

24

11

24

24

8

Warding off external interference is part of journalistic professionalism; therefore, incidents of interference should not be made public.

The amount of external interference I encounter in my work has increased during the past three years.

My managing editor, editor or supervisor gives in to external interference more easily than I do.

Politicians are able to influence the journalism my media outlet produces.

I prefer not to report about certain topics or present certain viewpoints due to external interference.

I have altered or removed something from my journalism pieces as I feared external interference. 
personally encountered by journalists has increased during the past three years $(33 \%$ agree, 39\% disagree) and whether external interference increases the mental strain of journalists' work (47\% agree, 33\% disagree). These results might indicate a division among journalists between those who are encountering increasing levels of interference and those who hardly encounter it at all. Previous studies in Western countries have suggested a connection between certain topics, labelled "trigger subjects" (Löfgren Nilsson \& Örnebring, 2016), and news as being associated with higher levels of interference, intimidation and harassment (Parker, 2015). This was supported by several survey respondents listing subjects and themes prone to generate external interference. In a 2016 survey, almost 40 per cent of threats received by members of the Union of Journalists in Finland were connected to coverage of immigration or multiculturalism. However, nearly half of the reported threats were connected to subjects other than the pre-given options, such as sexual minorities, religion, equality issues, healthcare, social security and Russia. The findings therefore highlight the wide range of seemingly random topics that generate threats (Marttinen, 2016).

\section{Discussion and conclusion}

According to the survey, the most common types of external interference were low-level interference in relation to source relations and access to information, and mediated verbal abuse. Overall, the majority of the various types of external interference were encountered only rarely and sporadically by Finnish journalists.

Despite the relative rarity of interference, we need to look beyond the immediate and direct effects. The consequences of interference are highly complex and mediated by factors such as societal climate, journalistic culture, perceived organisational support, professional identity and various individual-level factors (Parker, 2015). In particular acts of public harassment, defamation and intimidation can be seen as strategic communicational actions intended to send a message not only to the victim but to other journalists as well. (e.g. Kodellas et al., 2014; Nerone, 1994). The indirect consequences of interference and harassment can have a cumulative effect, fostering a culture of anxiety and self-censorship and producing a chilling effect on public discourse (see Clark \& Grech, 2017; Landsverk-Hagen, 2015; Löfgren Nilsson \& Örnebring, 2016). This type of dynamic was also reflected in some of the survey comments, as demonstrated below:

There is not that much external interference, but because of the general polarisation of the societal atmosphere I am not that keen to tell anybody that I am a journalist [...] It has become clearer that your occupation can be a threat to your safety. This is a psychological shift that has taken place over recent years [...] (translation by author)

This study has a number of limitations. Data collected through self-report surveys are prone to perceptual bias and individual differences when interpreting questions and deciding what to report. Excluding the comments, the survey did not distinguish between different sources, contexts or locales of interference. More elusive methods of influence that might be defined as interference in some contexts but not in others are especially difficult to measure. Whereas, for instance, incidents of explicit violence can be measured quite straightforwardly, the lines between maintaining good source relations and 
giving in to external interference and between ethical considerations and self-censorship can be blurry (e.g. Berkowitz, 2009). In addition, the lack of longitudinal data makes it impossible to identify any possible shifts or changes.

Further research is needed to explore the patterns and mechanisms revealed by the results. The next phase ought to focus on connections between various individual- and organisational-level factors and the degree to which journalists experience different types of external interference. In addition, future research should be conducted to account for the lack of qualitative understanding of external interference especially in the context of Western democratic countries.

\section{Funding}

This work was supported by the Media Industry Research Foundation of Finland under Grants 201610183 and 201710214, the University of Tampere and the Union of Journalists in Finland.

\section{Notes}

1. As defined by Chadwick (2017: 3-5), a hybrid media system is characterised by complex interdependence and a constant adaptation process between old and new forms of media. The proliferation of online communication and social media has blurred the lines between media producers and audiences, making it possible for new kinds of actors to participate in creating, steering and manipulating information flows.

2. For detailed account of study methodology, see WJS (2018).

3. The processing of quantitative survey data was conducted by research assistant, doctoral candidate Aleksi Suuronen (M.Soc.Sc).

4. The estimated organisation rate of journalists in Finland is approximately 90 per cent (Pöyhtäri et al., 2014: 4). The membership register of the Union of Journalists in Finland is the most exhaustive and up-to-date national database of Finnish journalists.

5. "Your work involves essential journalistic features and is professional in nature. 'Professional' in this context means that a significant portion of your earnings derive from such work that has essential journalistic qualities" (The Union of Journalists in Finland, 2017). All editors' associations' membership criteria included a managing position in a media outlet.

6. It should be noted that several WJS-surveys conducted online only had similar or lower response rates (e.g. Netherlands $10 \%$, UK $8 \%$ Italy $3.8 \%$ ).

7. Based on the membership statistics from 2015. To determine the age structure, employment type, employing media outlet and position, a limited sample was used omitting members (e.g. technical personnel, etc.) whose professional description was deemed not relevant to the scope of the study.

8. As stated before, some journalists in management positions cannot be accepted as union members, which largely explains their low share in union membership.

9. Pre-publication screening of journalistic content follows the Finnish Council for Mass Media's (2017) ethical guidelines: "It is worthwhile consenting to interviewees' requests to read their statements prior to publication, if the editorial deadline permits. This right only concerns the personal statements of the interviewee, and the final journalistic decision cannot be surrendered to any party outside the editorial office". In practice, this is often done by emailing the citations or the whole piece to allow interviewees to correct or clarify their statements. In this article, pre-screening refers to this practice.

\section{References}

Berkowitz, D. (2009). Reporters and their sources. In K. Wahl-Jorgensen \& T. Hanitzsch (eds.), The handbook of journalism studies (pp. 102-115). New York: Routledge.

Chadwick, A. (2017). The hybrid media system: Politics and power. Oxford: Oxford University Press.

Clark, M. \& Grech, A. (2017). Journalists under pressure: Unwarranted interference, fear and self-censorship in Europe. Strasbourg: Council of Europe Publishing.

Cook, C., Heath, F. \& Thompson, R. (2000). A meta-analysis of response rates in web- or internet-based surveys. Educational and Psychological Measurement 60(6): 821-836. 


\section{Ilmari Hiltunen}

Council for Mass Media (2016). Miksi JSN ei julkaise karsittuja kanteluja? [Why CMM does not publicise rejected complaints]. [online]. Retrieved from http://www.jsn.fi/blog/16-8-2016-miksi-jsn-ei-julkaise-karsittuja-kanteluja/. [accessed 2017, September 26].

Council for Mass Media (2017). Guidelines for journalists and an annex. [online]. Retrieved from http:// www.jsn.fi/en/guidelines_for_journalists/. [accessed 2017, December 15].

Deuze, M. (2005). What is journalism? Professional identity and ideology of journalists reconsidered. Journalism, 6(4): 442-464.

Finnish Newspapers Association (2016). Media-ala puolustaa yhteisvoimin vastuullista sananvapautta [The media industry stands united in defence of responsible freedom of speech]. [online]. Retrieved from http://www.sanomalehdet.fi/ajankohtaista/uutiset/media-ala-puolustaa-yhteisvoimin-vastuullista-sananvapautta-2. [accessed 2016, August 11].

Freedom House (2017). Freedom of the press - United States. [online]. Retrieved from https://freedomhouse. org/report/freedom-press/2017/united-states. [accessed 18 October, 2017].

Haapalainen, M. (2016). JSN: Toimittajien uhkailu vaarantaa sananvapautta [CMM: Intimidation of journalists jeopardises the freedom of speech]. [online]. Retrieved from http://www.journalisti.fi/ajankohtaiset/ jsn-toimittajien-uhkailulla-on-laajoja-haittavaikutuksia/. [accessed 11 August, 2016].

Hanitzsch, T. (2011). Populist disseminators, detached watchdogs, critical change agents and opportunist facilitators: Professional milieus, the journalistic field and autonomy in 18 countries. The International Communication Gazette, 73(6): 477-494.

Hemánus, P. (1983). Journalistinen vapaus [Journalistic freedom]. Helsinki: Gaudeamus.

Jann, B. \& Hinz, T. (2016). Research question and design for survey research. In C. Wolf, D. Joye, T. Smith \& Y-C. Fu (eds.), The SAGE handbook of survey methodology (pp. 105-121). London: Sage.

Kantola, A. \& Lounasmeri, L. (2014). Viestinnän ammattilaiset promootioyhteiskunnassa: aktivisteja ja ajatusjohtajia [Communication professionals in a promotion society: Activists and thought leaders]. Media \& Viestintä, 37(3): 3-21.

Kodellas, S., Papastavrou, N., Giannakoulopoulos, A. \& Koutsompolis, D. (2014). Journalists' victimization experiences and fear of crime at the workplace: Results of a questionnaire survey from Greece and Cyprus. European Journal of Communication, 29(4): 480-494.

Koivunen, A. (2017). \#Sipilägate and the break-up of the political bromance: Crisis in the relationship between Finnish Media and Politicians. Nordicom-Information, 39(1): 44-51.

Krosnick, J. (1999). Survey research. Annual Review of Psychology (50): 537-567.

Kunelius, R., Noppari, E. \& Reunanen E. (2010). Media vallan verkoissa [Media in the networks of power]. Tampere: University of Tampere.

Kunelius, R. (2003). Viestinnän vallassa: johdatusta joukkoviestinnän kysymyksiin [Mesmerised by communication: Introduction to questions of mass communication]. Helsinki: WSOY.

Kuutti, H. (ed.) (2011). Julkisuusjournalismi [Publicity journalism]. Jyväskylä: University of Jyväskylä.

Landsverk-Hagen, A. (2015). Meningers mot - netthat og ytringsfrihet i Norge [The courage of opinions internet hate and journalistic freedom of expression in Norway]. Oslo: Cappelen Damm Akademisk.

Löfgren Nilsson, M. (2016). Hoten och hatet mot journalister [Threats and hate towards journalists]. [online]. Retrieved from http://jmg.gu.se/digitalAssets/1577/1577351_jp9-trakasserier-journalister.pdf. [accessed 2017, September 20].

Löfgren Nilsson, M. \& Örnebring, H. (2016). Journalism under threat: Intimidation and harassment of Swedish journalists. Journalism Practice, 10(7): 880-890.

Luostarinen, H. (1994). Mielen kersantit: julkisuuden hallinta ja journalistiset vastastrategiat sotilaallisissa konflikteissa [Sergeants of the mind: Publicity control and Journalistic counter-strategies in military conflicts]. Helsinki: Hanki ja Jää.

Luque Martinez, J. (2015). Trolled by the state. British Journalism Review, 26(4): 61-66.

Marttinen, M. (2016) "Hakkaan sinut paskaksi" ["I will beat you to a pulp"]. Journalisti, March 17, 2016. [online]. Retrieved from < https://www.journalisti.fi/artikkelit/2016/4/hakkaan-sinut-paskaksi/>. [accessed 2017, January 18].

Mäntylä, J. (2008). Journalistin etiikka [Journalist ethics]. Helsinki: Gaudeamus.

Nerone, J. (1994). Violence against the press: Policing the public sphere in U.S. history. New York: Oxford University Press.

Noppari, E. \& Hiltunen, I. (2018). Populistinen vastamedia eliittejä haastamassa [Populist counter media challenging the elites]. In M. Niemi \& T. Houni (eds.), Media \& populismi - Työkaluja kriittiseen journalismiin [Media \& populism - Tools for critical journalism]. (pp. 236-272). Tampere: Vastapaino.

Nord, L. (2008). Comparing the Nordic media systems: North between west and east. Central European Journal of Communication, 1(1): 95-110.

Parker, K. (2015). Aggression against journalists: Understanding occupational intimidation of journalists using comparisons with sexual harassment. Oklahoma: University of Tulsa. 
Pietiläinen, T. (2007). Selkeyttä vai sensuuria? [Clarity or censorship?]. In S. Seppä (ed.), Journalismikritiikin vuosikirja 2007 [The yearbook of journalism critique]. (pp. 91-98). Tampere: University of Tampere.

Pöyhtäri, R., Ahva, L. \& Väliverronen, J. (2014). Mistä on suomalainen toimittaja tehty? Worlds of journalism - surveyn tuloksia Suomesta [What is the Finnish journalist made of? Worlds of journalism survey results from Finland]. Tampere: University of Tampere.

Reich, Z. \& Hanitzsch, T. (2013). Determinants of journalists' professional autonomy: Individual and national level factors matter more than organizational ones. Mass Communication and Society, 16(1): 133-156.

RSF (2016a). Suomi on jälleen lehdistönvapauden ykkösmaa [Finland is again the number one country for press freedom]. [online]. Retrieved from http://toimittajatilmanrajoja.com/fi/2016/04/20/tiedote-suomi-jalleen-lehdistonvapauden-ykkosmaa/. [accessed 2016, August 11].

RSF (2016b). Reporters without borders (RSF) remains concerned about actions taken by national broadcaster YLE. [online]. Retrieved from https://rsf.org/en/news/reporters-without-borders-rsf-remains-concerned-about-actions-taken-national-broadcaster-yle. [accessed 2017, November 15].

RSF (2017). Journalism weakened by democracy's erosion. [online]. Retrieved from https://rsf.org/en/journalism-weakened-democracys-erosion. [accessed 2017, October 18].

Shoemaker, P. \& Reese, S. (1996). Mediating the message: Theories of influences on mass media content. New York: Longman.

Sivo, S., Saunders, C., Chang, Q. \& Jiang, J. (2006). How low should you go? Low response rates and the validity of inference in is questionnaire research. Journal of the Association for Information Systems, 7(6): 351-414.

Sudman, S. \& Kalton, G. (1986). New developments in the sampling of special populations. Annual Review of Sociology, 12: 401-429.

The Union of Journalists in Finland (2017). Join the union. [online]. Retrieved from https://journalistiliitto. fi/en/membership/join-the-union/. [accessed 2017, November 15].

Trottier, D. (2017). Digital vigilantism as weaponisation of visibility. Philosophy \& Technology, 30(1): 55-72.

Waisbord, S. (2002). Antipress violence and the crisis of the state. Harvard International Journal of Press/ Politics, 7(3): 90-109.

Weaver, D. \& Elliott, S. N. (1985). Who sets the agenda for the media? A study of local agenda-building. Journalism \& Mass Communication Quarterly, 62(1): 87-94.

WJS (2018). The WJS 2012-2016 study. [online]. Retrieved from http://www.worldsofjournalism.org/research/2012-2016-study/. [accessed 2018, January 16]. 